This is the accepted version of an article that will be published in Feminist Review: Special Issue on Gender, Violence and the Neoliberal State in India:

https://link.springer.com/journal/volumesAndlssues/41305

Accepted version downloaded from SOAS Research Online: http://eprints.soas.ac.uk/25540/

\title{
Introduction
}

\section{Gender, Violence, and the Neoliberal State in India}

\section{Kalpana Wilson, Jennifer Ung Loh, Navtej Purewal}

Developing a gendered understanding of the neoliberal state has, not surprisingly, been a preoccupation for much recent feminist praxis in the Global North and particularly in the Global South. Sustained activism and scholarship has addressed a wide variety of questions, including the increased reproductive and productive labour demanded of women, the gendered effects of the privatisation of and dispossession from land, natural resources and public services, and the variegated and often apparently contradictory impacts of multiple incorporations into global markets (Elson, 1991, 2002; Sparr, 1994; Wright, 2006; Sharma 2010; Owens 2015; Farris 2017)). The state's role in attempts to produce women as gendered neoliberal subjects who are simultaneously entrepreneurial and altruistic, and the selective appropriation and incorporation of feminist ideas within the neoliberal discourses of states, global institutions, and their corporate partners has been explored, and a specifically 'neoliberal' feminism has been identified and delineated (Wilson, 2008, 2015; Chant and Sweetman, 2012; Rottenberg, 2014; Purewal, 2015). New forms of biopolitical regulation, intervention, and violence inherent in neoliberal governance (Sangari, 2015), gendered embodied experiences of marketised reproductive, agricultural, and environmental technologies (Rao and Sexton, 2010, Tandon, 2010, Fent, 2012), and of military occupations and the policing of bodies and borders (Puar, 2004; Osuri, 2015) have been analysed.

Much of this work has implicitly challenged the frequently assumed conflict between movements of social conservatism and the religious right on the one hand and the forces of neoliberal globalisation on the other, instead suggesting a need for further exploration of the synergies between the two, particularly in the context of the state's accentuated punitive functions, the criminalisation of excluded and demonised populations, and the targeted mobilisation of moral panics which characterise the governmentality of the neoliberal state. This is especially the case in India, where, since the International Monetary Fund (IMF)-led economic reforms of the early 1990s, oppressive gender ideologies have been extended and mobilised in the service of 'liberalisation, privatisation, globalisation' and in tandem with the promotion of a market-led version of women's empowerment. The last quarter century has witnessed both the emergence of a neoliberal consensus across mainstream political parties in India and the rise of the Hindu far right, with its political party, the Bharatiya Janata Party (BJP), being anointed as the pre-eminent party of neoliberalism and the preferred candidate of corporate capital.

The ascendance of Hindutva neoliberal political power requires significant interrogation of India's liberal, capitalist order. While gender violence is often viewed as an aberration within liberal discourses of women's protectionism and 'rights', we regard this order as one that has inherently and systematically, well before the BJP's 
2014 election victory, been hinged on the exclusionary, exploitative structural violence of the state. India's aggressive neoliberal growth strategy has involved both the extension and intensification of women's labour, discursively framed in familiar neoliberal terms of 'inclusion' and 'empowerment' as well as, increasingly, explicitly patriarchal social programmes of 'safety', 'security', and 'protection', which formally position women as carriers and symbols of patriarchal ideology and communal-religious boundaries. Moreover, the neoliberal strategies the state has pursued before and since May 2014 have led to the targeting of multiple 'disposable' populations, as part of the construction of an exclusionary vision of the modern nation.

The four years since the Narendra Modi Government was elected in 2014 have entailed the extension and intensification of multiple forms of gendered violence that are already deeply embedded in India's social and economic structures, and their mobilisation for the project of far-right Hindu nationalism, or Hindutva. Hindutva is the ideology of a network of organisations, paramilitaries, armed vigilante groups, and political parties, including Modi's BJP, and is guided by the avowedly fascist cadre-based organisation at the heart of this network, the Rashtriya Swayamsevak Sangh (RSS). The rise of so-called 'moral policing', in which women's sexual autonomy is explicitly and violently targeted, the incarceration and blackmailing of Hindu women who are in consensual relationships with Muslim men (spuriously branded 'Love Jihad') and the state sanctioning of the authority of patriarchal, caste-supremacist institutions such as 'Khap Panchayats' (Village Councils) are taking place alongside, and are inseparable from, a rising tide of state-sponsored attacks on religious minorities and Dalits. Within contemporary Hindutva, virulent Islamophobia, caste supremacism and patriarchal values are intertwined with a commitment to supporting the interests of neoliberal corporate capital through the intensification of gendered processes of exploitation, displacement, and dispossession. This Special Issue elaborates on the implications of this symbiotic relationship for multiple aspects of gendered lives in contemporary India.

As this collection of articles highlights, women have been placed at the forefront of the Hindu right's economic, political, and social agendas. Women are constructed variously according to their social location as subjects and bodies to be protected, exploited, placed under surveillance, morally and socially policed, or targeted by organised and state-sponsored violence. Violence is thus not an outcome of political and economic processes, but, rather, a core ingredient of capitalist 'development' under Hindutva governmentality.

Several notable overlapping themes arise in analysing the relationships between Hindutva, neoliberal policies (economic, social, and political), and gender violence in contemporary India. One significant link is the moral and social policing of bodies and relationships, as explored in Tanika Sarkar's special contribution, 'Is Love Without Borders Possible?' Sarkar's examination of campaigns mobilising the trope of 'Love Jihad' demonstrates the Hindu right's violent intervention into cross-religious, interpersonal relations, where pernicious Hindutva logics (Islamophobic, casteist, patriarchal) extend into personal lives and relationships. 
Kavita Krishnan's article, 'Gendered Discipline in Globalising India', addresses the neoliberal state's instrumentalisation of gendered surveillance and discipline and argues that the gendered narratives of the Hindutva state and its simultaneous aggressive pursuit of neoliberal 'development' are not mutually contradictory, sharing a deep hostility to and fear of women's autonomy. Suggesting that patriarchal surveillance and moral regimes within the family should be understood in terms of the structuring of women's labour in the household, Krishnan examines how this model is being extended by the state to higher education institutions and, in particular to a growing, globalised female workforce, and explores the implications of this approach for political dissent and labour organising.. Synergies of Hindutva and neoliberalism are further complicated by the policing of wider gender identities in society. Jennifer Ung Loh's article, 'Transgender Identity, Sexual versus Gender "Rights", and the Tools of the Indian State', analyses the limited and caveated ways in which transgender subjects accrue constitutional rights. Ung Loh argues that certain forms of transgender identity, as opposed to 'inauthentic' transgender and 'LGB' identities, are sanctioned in conjunction with larger right-wing conceptions of the nation and its citizens. Therefore, moral and social policing is an important consequence of Hindutvas's convergence with neoliberal logics, where certain identities, forms of labour, and indeed love, are permissible in a vision of a Hindu nationalist India.

The relationship between gender violence, gendered labour, neoliberal policies, and Hindutva is also considered in relation to reproductive technologies and violences. Navtej Purewal's article, 'Sex Selective Abortion, Neoliberal Patriarchy, and Structural Violence in India', examines sex selective abortion (SSA) as a form of structural violence. State-endorsed neoliberal patriarchy is being actively promoted through social campaigns and financial schemes to further entrench women and girls as dependents. Purewal argues that the Indian state duplicitously endorses gendered structural violence while appearing to oppose SSA through 'save the girl child' campaigns, financial inclusion banking schemes, and other awareness-raising initiatives. Kalpana Wilson's article, 'For Reproductive Justice in an Era of Gates and Modi - The Violence of India's Population Policies' addresses India's population policies, which, she argues, operate as a form of embodied, sometimes fatal, violence perpetrated by the state against poor, Adivasi, and Dalit women. Shaped by global, corporate-led neo-Malthusian population interventions, national 'family planning' policies simultaneously mobilise and re-embed the structural subordination of women belonging to marginalised and demonised communities. Further, Wilson explores how the violence of these policies is deepened by interrelated processes associated with the rise of Hindu supremacism, the intensification of women's labour for global capital, and corporate dispossession and displacement.

While the Special Issue addresses multiple forms of gendered violence being undertaken by the neoliberal, Hindutva state at a critical juncture, it simultaneously engages with the Indian state's long history of excluding populations marked by religion, nationality, caste, class, or sexuality from effective citizenship. As well as recognising how particular experiences have often been rendered invisible within mainstream feminist discourse, the Special Issue also seeks to underline the multiplicity of feminisms operating in and against the mainstream, notably by tracing 
some of the historical trajectories and contemporary expressions of Dalit feminism, and of gendered protest in the 'zones of exception' of Manipur and Kashmir.

Nitasha Kaul's article, 'India's Obsession with Kashmir: Democracy, Gender, (Anti)Nationalism', offers a gendered analysis of representation, cartography, and possession by examining hegemonic Indian nationalism and its stake in claiming Kashmir. The Indian state embodies and adopts the guise of a dominating, masculinist nation-state, acting with immunity and impunity. Kashmir's feminised body and the domestication of dissent on the Kashmir question has normalised and legitimised state violence and the state's obsessive claims to possess Kashmir. It is thus crucial to consider the actions of dispossessed populations in response to state violence, upon which Goldie Osuri also reflects in an Open Space contribution, 'Reflections on Witnessing with the Association of Parents of Disappeared Persons, Kashmir'. Osuri examines the rich and complex ways in which state violence is resisted through memory, history, and acts of witnessing, challenging state sovereignty in the face of ongoing bloodshed. This persistent coloniality and political abandonment poses key challenges to our understanding of gendered modes of resistance under emergency laws, as Sumi Madhok argues in her article, 'Representation, Political Subjectivation, and Gendered Politics of Protest in a "State of Exception". Through her analysis of the 'naked protest' of Manipur's Meira Peibis, Madhok questions the adequacy of existing theoretical frameworks of intersectionality and of bare life for understanding gendered protests in Manipur, and suggests that we need to pay attention to the corporeal and performative aspects of political subjectivation in such states of exception. The urgency of challenging dominant feminist understandings of gendered protests in contexts of exclusion from citizenship is further highlighted by engagement with Dalit and anti-caste politics. Meera Velayudhan's article, 'Linking Radical Traditions and the Contemporary Dalit Women's Movement: An Inter-Generational Lens', presents the trajectory of the contemporary Dalit women's movement, situated within a unique Dalit feminist, intergenerational radical tradition. Velayudhan explores the interrelationships between personal and historical memory and the emergence of the collective, locating and historicising the emergence of a 'new political imaginary' in the Dalit feminist movement, and the subsequent obstacles posed by the rise of neoliberal rights-based discourses. In a context of intensified caste-based and communal violence and acute state repression, the challenges of nurturing an anti-caste, feminist cultural movement are addressed further in 'Our Song Impure, Our Voice Polluted: Conversations with Activist and Musician, Shital Sathe', an Open Space contribution by Rasika Ajotikar. As Ajotikar highlights, Sathe's cultural activism as a Dalit woman shahir has challenged neoliberal and Brahmanical aesthetics of culture through anti-caste political assertions of voice and musicianship.

Many of the articles in this Special Issue grew out of presentations at a workshop held in London at SOAS, jointly organised by SOAS and the LSE Gender Institute in February 2015, almost one year after the 2014 election of the BJP. Now, three years later, in the context of India's deepening authoritarianism, silencing of dissent, and systematic state-sponsored Hindu supremacist violence against minority populations leading many to warn of a descent into fascism, this Special Issue aims to engage with 
This is the accepted version of an article that will be published in Feminist Review: Special Issue on Gender, Violence and the Neoliberal State in India:

https://link.springer.com/journal/volumesAndlssues/41305

Accepted version downloaded from SOAS Research Online: http://eprints.soas.ac.uk/25540/

and respond to growing debates around numerous forms of gender violence in India. It explores how various analyses have addressed - or rendered invisible - questions of class, caste, religion, sexualities, military occupation, and the state's embodied and structural violence, and how these analyses might serve to meet the challenges of the future.

\section{References}

Chant, S. and Sweetman, C. (2012) 'Fixing women or fixing the world? "smart economics", efficiency approaches, and gender equality in development' Gender and Development, 20 (3): 517-529

Elson, D (1991) 'Male Bias in Macro-economics: The Case of Structural

Adjustment', in D. Elson (ed.) Male Bias in the Development Process, pp. 164-190, Manchester: Manchester University Press.

Elson, D. (2002) 'Gender Justice, Human Rights and Neo-liberal Economic Policies', in M. Molyneux and S. Razavi (eds) Gender Justice, Development and Rights, pp. 78-114, Oxford: Oxford University Press.

Farris, S. (2017) In the Name of Women's Rights: The Rise of Femonationalism, Duke University Press: Durham.

Fent, A. (2012). Philanthropy and Sovereignty: A critical feminist exploration of the Gates Foundation's approach to gender and agriculture development. Reclaiming food sovereignty in Africa. Association of Concerned Africa Scholars, Bulletin No. 8, Fall, pp. $4-10$

Osuri, G. (2015) ‘Sovereignty, Postcoloniality, and Gendering Human Rights:

Rape and Occupation', borderlands e-journal, 14(1)

http://www.borderlands.net.au/vol14no1_2015/osuri_rape.pdf

Owens, P. (2015) Economy of Force: Counterinsurgency and the Historical Rise of the Social, Cambridge: Cambridge University Press. 
This is the accepted version of an article that will be published in Feminist Review: Special Issue on Gender, Violence and the Neoliberal State in India:

https://link.springer.com/journal/volumesAndlssues/41305

Accepted version downloaded from SOAS Research Online: http://eprints.soas.ac.uk/25540/

Puar, J (2004) ‘Abu Ghraib: Arguing against Exceptionalism', Feminist Studies 30(2): $522-34$

Purewal, N. (2015) 'Interrogating the Rights Discourse on Girls' Education:

Neocolonialism, Neoliberalism, and the Post-Beijing Platform for Action, IDS

Bulletin, 46 (4): 47-53.

Rao, M. and S. Sexton (2010) Eds. Markets and Malthus: Population, gender and health in neo-liberal times, New Delhi: Sage Publications.

Rottenberg, C. (2014) 'The Rise of Neoliberal Feminism', Cultural Studies 28(3): 418-37

Sangari, K. (2015) Solid: Liquid: A Transnational Reproductive Formation, Tulika Books: New Delhi.

Sharma, A. (2010) Paradoxes of Empowerment: Development, Gender and Governance in Neoliberal India, Zubaan: New Delhi.

Tandon, N. (2010) New agribusiness investments mean wholesale sell-out for women farmers, Gender \& Development, 18:3, 503-514

Wilson, K. (2008) 'Reclaiming “Agency”, Reasserting Resistance', IDS Bulletin 39(6): 83-91.

Wilson, K., 2015 'Towards a radical re-appropriation: Gender, development and neoliberal feminism', Development and Change, 46 (4), pp. 803-832

Wright, M. (2006) Disposable Women and Other Myths of Global Capitalism. London and New York: Routledge 